\title{
Corak Batik dan Perilaku Komunikasi \\ (Analisis Motif Batik Jogja dan Batik Solo)
}

\author{
Chelsea Yulianita, Gregorius Genep Sukendro \\ chelseayulianita3@gmail.com, geneps@untar.ac.id \\ Fakultas Ilmu Komunikasi Universitas Tarumanagara
}

\begin{abstract}
Batik is a characteristic of Indonesian national culture where the artworks in each style and motif have meaning, philosophy from each region. In this case culture and communication are very related. Communication behavior becomes the main thing in communicating. This study aims to determine the communication behavior found in the batik motifs of Jogja and Solo batik and find out the distinctive motifs of Jogja batik and Solo batik. The theory that I use is motive theory and communication behavior theory. Whereas my method uses descriptive qualitative research methods. With the method of data collection to be obtained from the results of in-depth interviews and observations. The results I get are communication behavior that occurs not only through verbal communication but also through non-verbal communication. On verbal communication the communication pattern leads to the provision of information about the meaning and meaning of the characteristics of Jogja and Solo batik motifs to the community. While the non-verbal communication communication patterns lead to messages and signs conveyed through symbols and images of the batik motif itself.
\end{abstract}

Keywords: Batik, communication behavior, the pattern of batik

\begin{abstract}
Abstrak
Batik merupakan ciri khas budaya bangsa Indonesia di mana karya seni ini pada setiap corak dan motifnya terdapat makna, filosofi dari masing-masing daerahnya. Dalam hal ini, budaya dan komunikasi sangat berhubungan. Perilaku komunikasi menjadi hal utama dalam berkomunikasi. Penelitian ini bertujuan mengetahui perilaku komunikasi yang terdapat pada motif batik Jogja, dan batik Solo dan mengetahui ciri khas motif yang dimiliki batik Jogja dan batik Solo. Teori yang digunakan adalah teori motif dan teori perilaku komunikasi. Sedangkan metode yang dipakai yakni metode penelitian kualitatif yang bersifat deskriptif. Dengan metode pengumpulan data yang akan diperoleh dari hasil wawancara mendalam dan observasi. Hasil yang diperoleh adalah perilaku komunikasi yang terjadi tidak hanya melalui komunikasi verbal tetapi juga melalui komunikasi non-verbal. Pada komunikasi verbal pola komunikasi mengarah pada pemberian informasi mengenai arti dan makna dari ciri-ciri motif batik Jogja dan batik Solo kepada masyarakat. Sementara pada komunikasi non-verbal pola komunikasinya mengarah pada pesan dan tanda yang disampaikan melalui simbol dan gambar dari motif batik itu sendiri.
\end{abstract}

Kata kunci: batik, perilaku komunikasi, motif batik 


\section{Pendahuluan}

Bangsa Indonesia adalah bangsa yang memiliki banyak suku, dari keberagaman tersebut muncullah keanekaragaman berupa budaya, kesenian serta kerajinan. Salah satu keunikan budaya Indonesia adalah batik. Pada tanggal 2 Oktober 2009, batik merupakan warisan budaya asli Indonesia yang diresmikan oleh UNESCO (Wulandari, 2011: 7). Batik mempunyai nilai seni yang tinggi dan dilestarikan turun menurun dari zaman ke zaman di berbagai daerah. Batik pun dipahami sebagai karya seni yang teknik pembuatan coraknya menggunakan cap atau canting dan kain yang dicelupkan dengan menggunakan bahan perintang warna corak yang diterapkan di atas kain. Kata batik diambil dari kata amba yang artinya kain, luas, lebar, dan titik yang artiannya mati atau titik, lalu berkembanglah menjadi batik, yang artiannya gabungan titik yang menjadi gambar luas dan lebar pada kain (Wulandari, 2011: 4).

Pada abad ke 12, seketika seni membatik sangat berkembang. Semula muncul di Pulau Jawa, terutama di daerah Yogyakarta dan Surakarta, dan batik mulai diperkenalkan meluas pada abad ke-17. Berawal batik dilukis di lontar daun, dengan berbentuk seperti hewan dan tumbuhan. Seiring berjalannya muncul dengan motif abstrak yang mirip awan, candi, dan wayang. Pada masa pra-Islam, Batik bermunculan di wilayah Galuh, Barat Laut Jawa. Beragam motif yang dimiliki batik tradisional coraknya disesuaikan dengan makna dan filosofi dari masing-masing daerahnya.

Sejarah batik di Indonesia berkaitan dengan Kerajaan Mataram Hindu dan Kerajaan Majapahit. Dalam perkembangannya masa Kerajaan Mataram Islam dilakukan banyak pembatikan dan dilanjutkan pada masa Keraton Yogyakarta dan Keraton Surakarta. Awalnya, batik dikhususkan untuk raja dan pengikutnya. Lalu karena banyak pengikut raja yang menetap di luar keraton, maka kesenian ini diangkut ke luar keraton dan dilakukan di rumah masing-masing abdi dalam.

Seiring dengan berkembangnya zaman, batik mengalami perkembangan mulai melahirkan berbagai jenis dan corak batik di Indonesia, corak dan variasi batik yang sangat beragam menunjukkan ciri khas dan budaya dari masing-masing setiap daerahnya. Salah satunya adalah motif batik Jogja dan batik Solo.

Sejarah batik Solo pun tidak terlepas dari adanya pengaruh Keraton. Bermula dari 4 abad yang lalu pada masa Kerajaan Pajang. Seperti halnya kerajaan ini kelanjutan dari Dinasti Demak yang memindahkan pemerintahannya dari Demak Bintoro ke Pajang. Berdirinya Keraton Surakarta pada tahun 1745 bersamaan pada perkembangan Batik Surakarta. Berawal dari perpecahan Keraton Yogyakarta dan Surakarta sebagai bagian dari perjanjian Giyanti tahun 1755, yang isinya seluruh busana Mataram dibawa ke Keraton Yogyakarta. Sedangkan, PB III memerintahkan kepada seluruh abdi dalem untuk membuat sendiri motif batik Gagrak Surakarta.

Masyarakat sangat bersemangat dalam pembuatan corak motif batik. Sehingga banyak motif batik yang bermunculan berkembang di masyarakat. Dan beberapa motif tersebut yang diizinkan untuk dipakai di lingkungan keraton (Sumber: http://batik.or.id/sejarah-batik-solo, diakses pada tanggal 16 Februari 2019, pada pukul 12.50).

Budaya dan komunikasi sangat berhubungan, dengan adanya perilaku komunikasi menjadi hal yang sangat penting dalam berkomunikasi. Komunikasi tidak hanya dibutuhkan sebagai pertukaran informasi dan penyampaian pesan tetapi dibutuhkan agar komunikasinya berlangsung dengan baik. Sehingga pesan-pesan tersebut dapat dilihat dari perilaku manusianya. Dengan adanya keberagaman motif 
batik Jogja dan batik Solo menunjukan karakteristik motif dan makna yang ada dalam setiap perilaku komunikasinya.

Maka dari itu, untuk menganalisis dan mengatahui lebih jauh tentang uraian latar belakang yang telah dipaparkan penulis tertarik melakukan penelitian berjudul "Corak Batik dan Perilaku Komunikasi (Analisis Motif Batik Jogja dan Batik Solo)"

Berdasarkan latar belakang masalah di atas, maka dalam hal ini penulis dapat merumuskan masalah penelitian diantaranya: bagaimana perilaku komunikasi yang terjadi pada motif batik Jogja dan batik Solo? Penelitian ini bertujuan untuk mengetahui perilaku komunikasi yang terjadi pada motif batik Jogja dan batik Solo, mengetahui ciri khas motif yang dimiliki pada batik Jogja, mengetahui ciri khas motif yang dimiliki pada batik Solo.

\section{Metodologi Penelitian}

Penelitian ini menggunakan penelitian kualitatif. Bogdan dan Taylor (dalam Moleong, 2011: 4) mengartikan metodologi kualitatif sebagai proses penelitian yang menghasilkan informasi data deskriptif kata-kata tertulis dan lisan dari orang-orang yang diamatinya. Peneliti memilih menggunakan metode penelitian kualitatif bersifat deskriptif dengan tujuan untuk memahami lebih dalam bagaimana motif corak batik Jogja dan batik Solo dalam mempengaruhi pola perilaku komunikasi. Metode penelitian deskriptif adalah suatu metode untuk meneliti status sekelompok manusia, suatu objek, suatu kondisi, suatu sistem pemikiran, ataupun suatu kelas peristiwa pada masa sekarang. Tujuannya membuat deskripsi, gambaran atau lukisan secara sistematis, faktual dan akurat mengenai fakta, sifat-sifat serta hubungan antar fenomena yang diselidiki (Nazir, 2011: 54).

Studi kasus merupakan strategi penelitian yang dipakai dalam penelitian ini. Peneliti memfokuskan diri pada sebuah fenomena (Bungin, 2010: 68). Unit pengelola museum dan pengrajin batik menjadi subyek yang peneliti pakai, sedangkan pola perilaku komunikasi yang ada pada motif batik Jogja dan batik Solo menjadi objek penelitian inilah. Pada penelitian ini, peneliti juga menggunakan dua metode untuk pengumpulan data yakni data primer yaitu wawancara dan observasi, dan data sekunder yaitu studi kepustakaan, dokumentasi dan data online.

Teknik analisis data yang digunakan penulis menurut Miler dan Huberman (dalam Gunawan, 2014: 210-212), yaitu yang pertama reduksi data penulis mereduksi data dengan cara pilih data-data, merangkum serta memfokuskan yang terkait dengan penelitian. Kedua penyajian data penulis melakukan penyajian data untuk mengkatagorikan data yang diperoleh dengan penyajian data memudahkan penulis untuk mendeskripsikan data sehingga dapat mudah dipahami dan dimengerti. Ketiga kesimpulan atau verivikasi penulis menarik kesimpulan dari data-data yang diperoleh.

Teknik triangulasi ialah teknik keabsahan data yang peneliti pakai, sebagai alat untuk menguji validasi data. Triangulasi merupakan suatu cara mendapatkan data yang benar dan absah dengan menggunakan pendekatan metode ganda (Gunawan, 2014: 219). 


\section{Hasil Temuan dan Diskusi}

\section{a. Motif Batik}

Dalam suatu karya batik, motif merupakan salah satu ornamen dalam batik yang sangat memberikan keindahan pada kain batik, sehingga motif batik merupakan gambar yang berpaduan antara bentuk, garis dan isen menjadi kesatuan bentuk yang membentuk keindahan (Susanto, 1980: 47).

Berdasarkan dengan hal tersebut unsur ornamen motif batik terdiri atas tiga bentuk utama diantaranya yaitu (Susanto, 1980: 212):

\section{1) Motif Utama}

Motif utama adalah suatu ragam hias yang menentukan dari pada motif tersebut, dan pada umumnya ornamen-ornamen utama itu masing-masing mempunyai arti atau makna sehingga susunan ornamen-ornamen itu dalam suatu motif membuat jiwa atau arti dari pada motif itu sendiri.

Pada motif utama batik sidomukti terdiri dari beberapa susunan ornamen mulai dari ornamen kupu-kupu, ornamen singgasana, lalu ornamen meru dari ketiga ornamen tersebut memiliki arti dan maknanya sendiri bagi si pemakai batik sidomukti tersebut. Ornamen kupu-kupu melambangkan harapan yang indah, ornamen singgasana yang bentuknya seperti tahta melambangkan kedudukan yang tinggi ingin dapat dihormati banyak orang, sedangkan ornamen meru bentuknya seperti gunung melambangkan keagungan yang abadi dalam dirinya.

\section{2) Motif Tambahan}

Motif tambahan adalah ornamen yang tak memiliki artian dalam pembentukan sebuah motif dan berguna untuk pengisian bidang.

Motif tambahan ini hanya terdiri dari ornamen bunga yang dimana bunga pada motif sidomukti menjadi simbol keindahan dan kecantikan bagi setiap orang.

\section{3) Isen-isen Motif}

Isen-isen motif adalah gabungan titik, garis yang berguna dalam pengisian ornamen dari motif tersebut atau pengisi bidang diantara ornamentornament lainnya.

Isen motif batik sidomukti terdri dari cecek, cecek pitu, sawut dan ukel. Lalu memiliki arti yang berbeda-beda mulai dari cecek sebagai pengisi motif batik yang bentuknya titik kecil, sedangkan cecek pitu bentuknya titik yang berjumlah tujuh, kemudian sawut sebagai pengisi daun yang bentuknya garis, yang terakhir ukel sebagai hiasan daun yang bentuknya keriting.

\section{b. Perilaku Komunikasi}

Menurut Deddy Mulyana didalam bukunya yang berjudul Ilmu Komunikasi Suatu Pengantar, Komunikasi dibagi menjadi dua yaitu komunikasi verbal dan komunikasi non-verbal. Komunikasi verbal ialah semua lambang yang digunakan dalam satu kata atau lebih. Bahasa verbal ialah bentuk utama dalam menyatakan pikiran dan maksud dari kita. (Mulyana, 2013: 260-261). 
Komunikasi verbal yang terjadi ketika pengrajin batik memberikan pengajaran dan informasi kepada karyawannya seputar motif-motif batik yang diproduksinya kemudian mengkomunikasikan jenis-jenis motifnya dengan baik dan jelas kepada setiap pelanggannya. Hal ini sejalan dengan komunikasi yang terjadi pada pengunjung museum tekstil melalui informasi yang disampaikan dengan menjelaskan arti dan makna dari setiap ciri motif batik Jogja dan Solo akan mudah dimengerti oleh penerimanya.

Sedangkan komunikasi non-verbal ialah semua perangsangan terkecuali perangsangan verbal di dalam setting komunikasi yang dimiliki seseorang dan pemakaian lingkungan pada seseorang yang mempunyai pesan untuk penerima dan pengirim dalam tingkah laku dimana disengaja maupun tidak disengaja dalam sebuah peristiwa komunikasi keseluruhannya (Mulyana, 2013: 343).

Komunikasi non-verbal dapat terjadi dalam melestarikan batik Jogja dan Solo melalui pesan atau simbol dari sebuah makna yang terdapat dalam setiap motif batik itu sendiri dengan tidak menghilangkan karakteristik dan ciri khas dari motif batik itu sendiri.

\section{Simpulan}

Batik menjadi salah satu ciri budaya bangsa Indonesia dengan ciri khas pada segi warna dan bentuk. Batik Jogja mempunyai warna yang cenderung lebih terang dibandingkan dengan batik Solo yang lebih gelap, sedangkan dari bentuk motifnya batik Jogja mempunyai dimensi ukuran motif yang lebih besar dibandingkan dengan batik Solo yang cenderung lebih kecil.

Pada komunikasi verbal, pola komunikasi mengarah pada pemberian informasi tentang arti dan makna dari ciri-ciri motif batik Jogja dan batik Solo kepada masyarakat atau konsumen seputar motif-motif yang akan diproduksi dan dijual. Sementara pada komunikasi non-verbal pola komunikasinya mengarah pada pesan dan tanda yang disampaikan melalui simbol dan gambar dari motif batik itu sendiri.

Perbedaan diantara motif Batik Jogja dan Batik Solo, perilaku komunikasi yang terjalin tetap sama tidak memberikan perbedaan. Hal ini dikarenakan kedua motif tersebut sama-sama menyampaikan makna dari tiap motif batik tersebut serta untuk melestarikan dan menjaga budaya kita sendiri.

\section{Daftar Pustaka}

Bungin, Burhan. (2010). Penelitian Kualitatif:Komunikasi, Ekonomi Kebijakan Publik, dan Ilmu Sosial Lainnya. Jakarta: Kencana Prenada Media Group.

Gunawan, Imam. (2014). Metode Penelitian Kualitatif Teori dan Praktik. Jakarta: PT. Bumi Aksara.

http://batik.or.id/sejarah-batik-solo

https://sembungbatik.wordpress.com/sejarah-dan-perkembangan-batik-di-indonesia

Moleong, M.A Lexy J. (2011). Metodologi Penelitian Kualitatif. Bandung: PT. Remaja Rosdakarya.

Mulyana, Deddy. (2013). Ilmu Komunikasi Suatu Pengantar. Bandung: PT. Remaja Rosdakarya.

Nazir, Mohammad. (2011). Metode Penelitian. Bogor: Ghalia Indonesia. 
Susanto, Sewan. (1980). Seni Kerajinan Batik Indonesia. Jakarta: Balai Penelitian Batik dan kerajinan, Lembaga Penelitian dan Pendidikan Industri, Departemen Perindustrian RI.

Wulandari, Ari. (2011). Batik Nusantara: Makna Filosofis, Cara Pembuatan dan Industri Batik. Yogyakarta: Andi. 